\title{
Organochlorine Pesticides in Human Serum
}

\author{
Jung-Ho Kang and Yoon-Seok Chang \\ Pohang University of Science and Technology (POSTECH) \\ Republic of Korea
}

\section{Introduction}

Organochlorine pesticides are a group of chlorinated compounds that persist in the environment. They were used mainly in agriculture and for pest control in cities for several decades. Their widespread use has resulted in their ubiquitousness in various environments and bioaccumulation throughout the food chain. Although many organochlorine pesticides are banned, their accumulation can have adverse effects on human health and the environment. In this chapter, we emphasize the organochlorine pesticides listed by the Stockholm Convention on persistent organic pollutants: aldrin, chlordanes, dieldrin, endrin, heptachlor, heptachlor epoxide, hexachlorobenzene (HCB), mirex, dichlorodiphenyltrichloroethanes (DDTs), toxaphene, and hexachlorcyclohexanes (HCHs). As these organochlorine pesticides have similar physicochemical properties, they can be analyzed by using the same analytical procedures, which are composed of extraction, cleanup, and selective and sensitive detection via gas chromatography with an electron capture detector, mass spectrometry, and high resolution mass spectrometry. The application of gas chromatography and high resolution mass spectrometry with an isotope dilution method provides highly accurate and reliable data. We describe a comprehensive extraction and purification method for analysis of target organochlorine pesticides and a measurement method using several equipments later in this chapter.

Many studies have revealed that the general population (including neonates), who lack occupational exposure to organochlorine pesticides, is exposed to background environmental levels of these chemicals. Among the organochlorine pesticides investigated, $p, p^{\prime}$-DDE, $\beta-\mathrm{HCH}$, hexachlorobenzene, $p, p^{\prime}$-DDT, oxychlordane, and trans-nonachlor were frequently detected in human serum which are comparatively convenient human biological specimens obtained from all individuals. Epidemiologic research has revealed that these chemicals are associated with several health disorders. Therefore, we conclude this chapter with a summary and critical review on the status of organochlorine pesticides in serum of the general human population.

\section{Characteristics of organochlorine pesticides}

Organochlorine pesticides have similar chemical structures, showing chlorine-substituted aliphatic or aromatic cyclic rings. Because of the structural similarities, these pesticides share certain physicochemical characteristics such as persistence, toxicity, bioaccumulation, and long-range transport potential. As a result, the Stockholm Convention considered some organochlorine pesticides as environmental hazards and listed them as persistent organic 
pollutants. The Convention is global treaty to protect human health and the environment from persistent organic pollutants.

Organochlorine pesticides persist in the environment. Persistency is defined as a half-life greater than two months in water or six months in soil and sediment. These chemicals are difficult to degrade into less hazardous substances in the environment. They are lipophilic compounds that tend to bioaccumulate in fatty tissues through the food chain. Bioaccumulation of organochlorine pesticides is defined as a $\log \mathrm{K}_{\mathrm{OW}}$ value greater than five or bioaccumulation factor in aquatic species greater than 5000. These pesticides are water insoluble and semivolatile, enabling their entry in the atmosphere and transport over long distances globally, mainly by air mass movements. They can reach polar or high mountainous regions and are effectively deposited in cold regions by snow through the phenomenon of cold condensation and global distillation (Wania and Mackay, 1995). Shen and Wania (2005) derived and compiled select physicochemical properties, including vapor pressure, water solubility, Henry's law constant $(H)$, octanol-water partition coefficient $\left(\mathrm{K}_{\mathrm{OW}}\right)$, and octanol-air partition coefficient $\left(\mathrm{K}_{\mathrm{OA}}\right)$ of major organochlorine pesticides (Shen and Wania, 2005). These properties have been used to screen the many chemicals for persistent organic pollutants criteria (Muir and Howard, 2006).

\subsection{Dichlorodiphenyltrichloroethane}

Dichlorodiphenyltrichloroethane (DDT) is the common name of 1,1,1-trichloro-2,2-di-(4chlorophenyl)ethane. Technical-grade DDT is a mixture of up to 14 compounds (Fig. 1). The active ingredient is $p, p^{\prime}$-DDT $(65-80 \%)$. The other compounds include $15-21 \%$ of $o, p^{\prime}$-DDT, up to $4 \%$ of $p, p^{\prime}$-DDD and 1-( $p$-chlorophenyl)-2,2,2-trichloroethanol, and traces of $o, o^{\prime}$-DDT and bis(p-chlorophenyl)sulfone. Othmar Zeidler, an Austrian scientist, first synthesized DDT in 1874. Paul Hermann Müller, a Swiss chemist who received the Nobel Prize in 1948 by the discovery of its insecticidal properties in 1939; it was widely used as an agricultural insecticide after the war. DDT easily degrades into dichlorodiphenyldichloroethane (DDD) and dichlorodiphenyldichloroethylene (DDE), which are more persistent than the parent compound. The half-life of $p, p^{\prime}$-DDE in humans has been estimated as more than 7 years<smiles>Clc1ccc(C(c2ccc(Cl)cc2)C(Cl)(Cl)Cl)cc1</smiles>

$\mathrm{p}, \mathrm{p}^{\prime}-\mathrm{DDT}$<smiles>Clc1ccc(C(c2ccccc2Cl)C(Cl)(Cl)Cl)cc1</smiles>

o,p'-DDT<smiles>Clc1ccc(C(c2ccc(Cl)cc2)C(Cl)Cl)cc1</smiles>

p,p'-DDD<smiles>Clc1ccc(C(c2ccccc2Cl)C(Cl)Cl)cc1</smiles>

o,p'-DDD<smiles>ClC(Cl)=C(c1ccc(Cl)cc1)c1ccc(Cl)cc1</smiles>

$p, p^{\prime}-D D E$<smiles>ClC(Cl)=C(c1ccc(Cl)cc1)c1ccccc1Cl</smiles>

o,p'-DDE

Fig. 1. Structures of dichlorodiphenyltrichloroethane analogues 
(Axmon and Rignell-Hydbom, 2006). In the 1970s and 1980s, most countries banned the agricultural use of DDT. It was restricted in the United States in 1972 and finally banned in 1979. Agricultural use continues in some countries, and developing countries use about 4000-5000 tonnes annually for vector control applications.

\subsection{Hexachlorcyclohexanes}

Hexachlorcyclohexanes (HCHs) are broad-spectrum insecticides used on fruits, vegetables, and forest crops. They are available as two commercial formulations. Technical-grade $\mathrm{HCH}$ is a mixture of isomers containing mostly $64 \% \alpha-\mathrm{HCH}, 10 \% \beta-\mathrm{HCH}, 13 \% \gamma-\mathrm{HCH}, 9 \% \delta$ $\mathrm{HCH}$, and $1 \% \varepsilon-\mathrm{HCH}$ (Fig. 2). The other commercial formulation contains more than $99 \% \gamma$ $\mathrm{HCH}$ (lindane). Micheal Faraday discovered HCHs in 1825 and Bender determined their insecticidal properties in 1935. Slade showed that $\gamma-\mathrm{HCH}$ was the only active insecticide of technical-grade $\mathrm{HCH}$ in 1942. Technical-grade $\mathrm{HCH}$ has been commercially produced since 1947. China and India, the two main users of technical-grade $\mathrm{HCH}$ globally, stopped its agricultural use in 1983 and 1990, respectively. The half-life of $\beta-\mathrm{HCH}$ in blood is 7 years, whereas $\gamma-\mathrm{HCH}$ has a half-life of only 20 hours.<smiles>Cl[C@H]1[C@H](Cl)[C@H](Cl)[C@@H](Cl)[C@@H](Cl)[C@H]1Cl</smiles>

$\alpha-\mathrm{HCH}$<smiles>Cl[C@H]1[C@H](Cl)[C@H](Cl)[C@@H](Cl)[C@@H](Cl)[C@H]1Cl</smiles>

$\beta-\mathrm{HCH}$<smiles>Cl[C@H]1[C@H](Cl)[C@H](Cl)[C@@H](Cl)[C@@H](Cl)[C@H]1Cl</smiles>

$\gamma-\mathrm{HCH}$<smiles>Cl[C@H]1[C@H](Cl)[C@H](Cl)[C@@H](Cl)[C@@H](Cl)[C@H]1Cl</smiles>

$\delta-\mathrm{HCH}$

Fig. 2. Structures of hexachlorcyclohexane isomers

\subsection{Chlordane}

Chlordane was used as a contact insecticide for agricultural crops and lawns, and for termite control in buildings. It has been commercially produced since 1947. Technical-grade chlordane is a mixture of at least 23 compounds and typically consists of $15 \%$ cis-chlordane, 15\% trans-chlordane, 9.7\% trans-nonachlor, 3.9\% heptachlor, 3.8\% cis-nonachlor, other chlorinated hydrocarbons, and by-products (Fig. 3). Nonachlor is an impurityies of technical chlordane. Oxychlordane is an oxidized form of chlordane. In the United States, the use of chlordane on food crops was ceased in 1978 and all uses were banned after 1988.

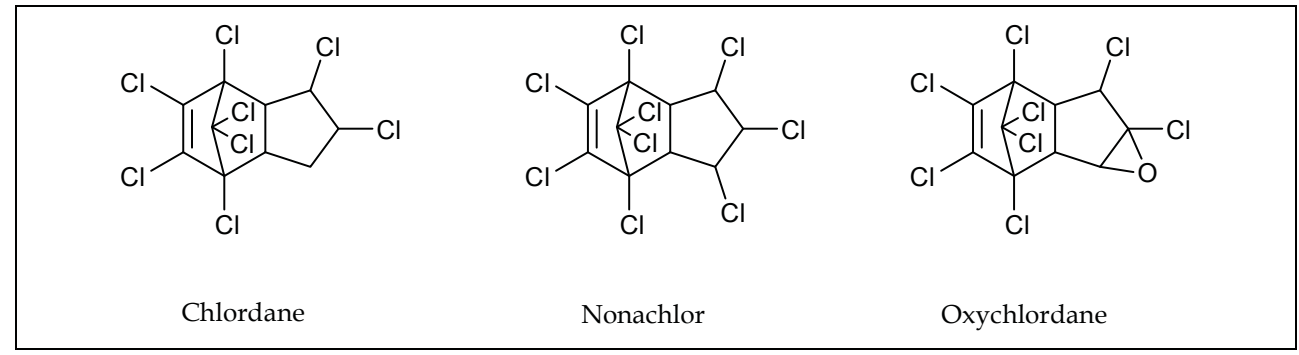

Fig. 3. Structures of chlordane, nonachlor, and oxychlordane 


\subsection{Heptachlor and heptachlor epoxide}

The chemical structure of heptachlor is similar to that of chlordane (Fig. 4). Heptachlor has been used as an insecticide to control fire ants. It is rapidly oxidized by both photochemical and biological processes to heptachlor epoxide, which is an oxidation product of heptachlor. Thus, heptachlor epoxide appears after the use of heptachlor. Heptachlor use was voluntarily discontinued in 1987 in the United States.<smiles>ClC1=C(Cl)C2(Cl)C3C(Cl)C=CC3C1(Cl)C2(Cl)Cl</smiles>

Heptachlor<smiles>ClC1=C(Cl)C2(Cl)C3C(Cl)C4(Cl)C(Cl)(Cl)C3(Cl)C1C24Cl</smiles>

Heptachlor epoxide

Fig. 4. Structures of heptachlor and heptachlor epoxide

\subsection{Aldrin, dieldrin, and endrin}

Aldrin, dieldrin, and endrin were used as insecticides from the 1950s to the mid-1970s. They have a similar structure (Fig. 5). Aldrin was first synthesized in 1948 and commercially manufactured in 1950. It is the common name of 1,2,3,4,10,10-hexachloro-1,4,4a,5,8,8ahexahydro-exo-1,4-endo-5,8-dimethanonapthalene, and technical-grade aldrin contains $90 \%$ of aldrin. Dieldrin, a pesticide product, is the oxygenated metabolite of aldrin. Aldrin easily degrades into dieldrin and is therefore rarely detected in the environment. Endrin was introduced in 1951 and primarily used as a cotton insecticide. It is a stereoisomer of dieldrin and is rapidly metabolized in the environment. Endrin aldehyde and endrin ketone are its degradation products. In most countries, aldrin, dieldrin, and endrin are banned for agricultural use and severely restricted for nonagricultural applications. Agricultural use of these chemicals was banned in 1970 and all uses were banned in 1987 in the United States.<smiles>ClC1=C(Cl)C2(Cl)C3C(Cl)C=CC3C1(Cl)C2(Cl)Cl</smiles>

Aldrin<smiles>ClC1=C(Cl)C2(Cl)C3C4OC4C3C1(Cl)C2(Cl)Cl</smiles>

Dieldrin<smiles>ClC1=C(Cl)C2(Cl)C3C4OC4C3C3C1C2(Cl)C3(Cl)Cl</smiles>

Endrin

Fig. 5. Structures of aldrin, dieldrin, and endrin

\subsection{Mirex}

Mirex was synthesized in 1946 and has been used as a pesticide since 1955. It is produced by the dimerization of hexachlorocyclopentadiene in the presence of aluminum chloride (Fig. 6). Mirex was used not only as an insecticide to control fire ants but also as a flame-retardant 
in plastic, rubber, paint, paper, and electrical goods. Hooker Chemical developed mirex as a chlorinated flame-retardant under the trade name Dechlorane. Its use as a pesticide was banned in the United States in 1978. Dechlorane was replaced by Dechlorane Plus in 1972.

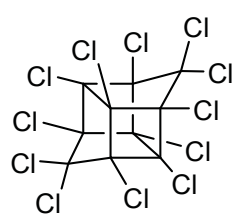

Mirex

Fig. 6. Structure of mirex

\subsection{Hexachlorobenzene}

Hexachlorobenzene (HCB) was introduced in 1945 as a fungicide for seed treatment (Fig. 7). It is formed as a by-product or an impurity during chemical and pesticide manufacture, and unintentionally produced by incomplete combustion in municipal solid waste incinerators and industrial processes. Most countries have banned or severely restricted its use as a pesticide. Hexachlorobenzene was banned in the United States in 1984.<smiles>Clc1c(Cl)c(Cl)c(Cl)c(Cl)c1Cl</smiles>

Hexachlorbenzene

Fig. 7. Structure of hexachlorobenzene

\section{Methods for analysis of organochlorine pesticides in human serum}

\subsection{Sample preparation of serum for analysis}

The literature describes several preparation methods to measure organochlorine pesticides in human serum (Barr et al., 2003; Sandau et al., 2003; Focant et al., 2004; Conka et al., 2005; Ramos et al., 2007). The standard method consists of three steps: denaturation, extraction, and cleanup.

Either organic solvents (methanol, propanol, or acetonitrile) or acids (acetic acid, formic acid, and hydrochloric acid) are used for denaturation of the serum protein. As formic acid does not destroy acid-sensitive pesticides such as cyclodienes, it is widely used for denaturation (Sandau et al., 2003). The serum sample can also be denaturated with hydrochloric acid and 2-propanol (Hovander et al., 2000).

Serum samples are extracted by using liquid liquid extraction or solid-phase extraction. The conventional method is liquid liquid extraction with an organic solvent such as hexane; 
however, this method is laborious and time consuming, and thus unsuitable for large-scale biomonitoring in epidemiologic studies. On the other hand, solid-phase extraction is a simple and efficient method. Commonly, a $\mathrm{C}_{18}$ solid-phase extraction cartridge is used for organochlorine pesticide extraction because the reverse-phase sorbent retains most organic analytes from aquatic matrices. $C_{18}$ (octadecyl) is bonded to the silica surface to provide nonpolar interactions with the analytes. The Oasis HLB cartridge, a polymeric waterwettable reverse-phase sorbent, can be used for organochlorine pesticide extraction without additional lipid cleanup steps (Sundberg et al., 2006). Each of these sorbents exhibits unique properties of retention and selectivity for organochlorine compounds.

The extract is purified by using several kinds of cleanup methods to remove interferences such as lipids. These methods include conventional glass columns or solid-phase extraction cartridges with neutral silica, florisil, and acid silica. For additional cleanup steps, sulfuric acid treatment, gel permeation chromatography, and active carbon treatment can be added according to interferences. Of the organochlorine pesticides discussed here, heptachlor epoxide, aldrin, dieldrin, and endrin are sensitive to concentrated sulfuric acid. To analyze acid-sensitive pesticides, sulfuric acid treatment and sulfuric acid silica should be avoided during the cleanup steps (Goni et al., 2007). Extraction and cleanup steps with an adequate solid-phase extraction cartridge have advantages such as simplicity, ease of automation, and high throughput.

The typical analytical methods for serum analysis recommended by the Centers for Disease Control and Prevention (CDC) are followed, with minor modifications (Barr et al., 2003; CDC, 2003; Kang et al., 2008). In brief, serum samples (1-2 mL) are spiked with ${ }^{13}$ C-labeled cleanup standards of organochlorine pesticides (ES-5349; Cambridge Isotope Laboratories, USA) and allowed to equilibrate. The samples are denatured and diluted with an equal amount of formic acid and water. The mixtures are remixed to ensure homogeneity and then loaded into preconditioned $\mathrm{C}_{18}$ solid-phase extraction cartridges. Each cartridge is dried and then eluted with $16 \mathrm{~mL}$ hexane, followed by concentration of the eluate to less than $6 \mathrm{~mL}$. The eluate is applied to a silica gel/florisil solid-phase extraction cartridge and then eluted with $12 \mathrm{~mL}$ hexane followed by $12 \mathrm{~mL}$ dichloromethane/hexane (1:1, v/v). The cleaned extracts are concentrated with a gentle stream of nitrogen and transferred to vials. The solvents are evaporated at room temperature with dodecane. Before instrumental analysis, the samples are reconstituted with ${ }^{13} \mathrm{C}$-labeled recovery standards (EC-5350; Cambridge Isotope Laboratories).

\subsection{Instrumental analysis}

After serum sample preparation, the cleaned extracts are analyzed by gas chromatography with several detectors including an electron capture detector, mass spectrometry, and high resolution mass spectrometry. An electron capture detector is one of the most sensitive detectors to measure halogenated compounds. Gas chromatography with an electron capture detector is employed because of the low cost and ease of operation as well as high sensitivity to organochlorine pesticides. However, this technique cannot differentiate co-eluted compounds. A DB-5 capillary column ( $30 \mathrm{~m}$ height $\times 0.25 \mathrm{~mm}$ inner diameter $\times 0.25 \mu \mathrm{m}$ film thickness) is widely used to identify and quantify organochlorine pesticides in human serum. Some pesticides cannot be completely separated in these column conditions. The usual coeluted organochlorine pesticides are heptachlor epoxide and oxychlordane (Fig. 8).

Gas chromatography with mass spectrometry can resolve the problem of co-elution and avoid misidentification of analytes if operated in the selected ion monitoring mode. 
However, the current serum concentrations of some organochlorine pesticides in the general population are too low for quantification by gas chromatography with an electron capture detector or gas chromatography with mass spectrometry. Mass spectrometry allows quantification by isotope dilution. Gas chromatography-high resolution mass spectrometric analysis with an isotope dilution method enables better identification and quantification than the other methods mentioned here. Chemically, the analytes and ${ }^{13} \mathrm{C}$-labeled analogues behave identically. However, they are distinguishable by their mass differences, allowing complete and automatic recovery correction for each analyte in each sample (Barr et al., 2003). To increase the sensitivity, the selected ion monitoring mode is also used during gas chromatography-high resolution mass spectrometric analysis.

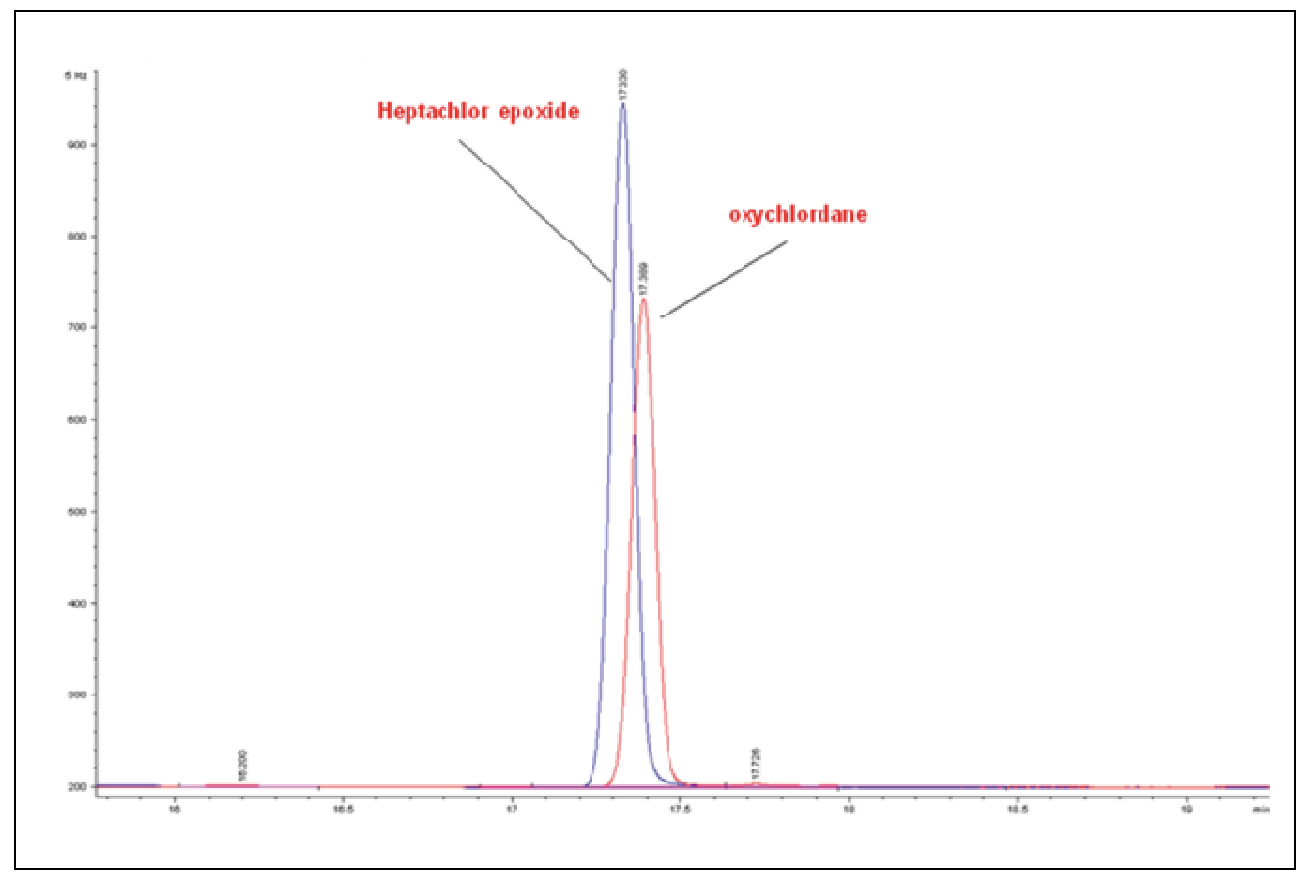

Fig. 8. Overlapping chromatograms of heptachlor epoxide and oxychlordane by gas chromatography with an electron capture detector

The state-of-the-art analytical method for organochlorine pesticides is isotope dilution gas chromatography-high resolution mass spectrometric quantification. This method is mandatory for PCDD/Fs and coplanar PCB analysis to achieve high sensitivity and precise quantification at low environmental levels. The Centers for Disease Control and Prevention have developed an isotope dilution gas chromatography-high resolution mass spectrometric method for quantification of organochlorines pesticides in human serum samples (CDC, 2003). The isotope-labeled pesticide standards and isotope dilution method support gas chromatography-high resolution mass spectrometric analysis (Kumar et al., 2005). For quantification of 22 persistent organochlorine pesticides, ${ }^{3}$ C-labeled cleanup internal standards, recovery standards, and calibration standards have been commercially available at Cambridge Isotope Laboratories since 2006 (Kang et al., 2008). 


\begin{tabular}{|c|c|c|c|c|c|}
\hline Group & Compound & Monitor & Ion 1 & Monitor & Ion 2 \\
\hline \multirow{7}{*}{$\begin{array}{l}\text { Group 1 } \\
(15.0-22.3)\end{array}$} & $\mathrm{HCH}$ & 216.9145 & {$[\mathrm{M}]^{+}$} & 218.9155 & {$[\mathrm{M}+2]^{+}$} \\
\hline & ${ }^{13} \mathrm{C}_{6}-\mathrm{HCH}$ & 222.9347 & {$[\mathrm{M}]^{+}$} & 224.9117 & {$[\mathrm{M}+2]^{+}$} \\
\hline & $\mathrm{HCB}$ & 283.8102 & {$[\mathrm{M}+2]^{+}$} & 285.8072 & {$[\mathrm{M}+4]^{+}$} \\
\hline & ${ }^{13} \mathrm{C}_{6}-\mathrm{HCB}$ & 289.8303 & {$[\mathrm{M}+2]^{+}$} & 291.8273 & {$[\mathrm{M}+4]^{+}$} \\
\hline & Heptachlor & 271.8102 & {$[\mathrm{M}+2]^{+}$} & 273.8072 & {$[\mathrm{M}+4]^{+}$} \\
\hline & ${ }^{13} \mathrm{C}_{10}$-Heptachlor & 276.8269 & {$[\mathrm{M}+2]^{+}$} & 278.8240 & {$[\mathrm{M}+4]^{+}$} \\
\hline & ${ }^{13} \mathrm{C}_{12}-\mathrm{CB}-15$ & 234.0406 & & 226.9287 & \\
\hline \multirow{7}{*}{$\begin{array}{l}\text { Group } 2 \\
(22.3-23.5)\end{array}$} & Aldrin & 262.8570 & {$[\mathrm{M}+2]^{+}$} & 264.8541 & {$[\mathrm{M}+4]^{+}$} \\
\hline & ${ }^{13}$ C-Aldrin & 269.8805 & {$[\mathrm{M}+2]^{+}$} & 271.8775 & {$[\mathrm{M}+4]^{+}$} \\
\hline & Oxychlordane & 386.8053 & {$[\mathrm{M}+2]^{+}$} & 388.8024 & {$[\mathrm{M}+4]^{+}$} \\
\hline & ${ }^{13} \mathrm{C}_{10}$-Oxychlordane & 396.8388 & {$[\mathrm{M}+2]^{+}$} & 398.8358 & {$[\mathrm{M}+4]^{+}$} \\
\hline & Heptachlor Epoxide & 352.8442 & {$[\mathrm{M}+2]^{+}$} & 354.8413 & {$[\mathrm{M}+4]^{+}$} \\
\hline & ${ }^{13} \mathrm{C}_{10}$-Heptachlor Epoxide & 362.8778 & {$[\mathrm{M}+2]^{+}$} & 364.8748 & {$[\mathrm{M}+4]^{+}$} \\
\hline & ${ }^{13} \mathrm{C}_{12}-\mathrm{CB}-70$ & 301.9626 & & 303.9597 & \\
\hline \multirow{6}{*}{$\begin{array}{l}\text { Group } 3 \\
(23.5-24.25)\end{array}$} & $\mathrm{o}, \mathrm{p}^{\prime}-\mathrm{DDE}$ & 246.0003 & {$[\mathrm{M}]^{+}$} & 247.9975 & {$[\mathrm{M}+2]^{+}$} \\
\hline & ${ }^{13} C_{12}-0, p^{\prime}-D D E$ & 258.0406 & {$[\mathrm{M}]^{+}$} & 260.0376 & {$[\mathrm{M}+2]^{+}$} \\
\hline & Chlordane (trans, cis) & 372.8260 & {$[\mathrm{M}+2]^{+}$} & 374.8231 & {$[\mathrm{M}+4]^{+}$} \\
\hline & ${ }^{13} C_{10}$-trans-Chlordane & 382.8595 & {$[\mathrm{M}+2]^{+}$} & 384.8566 & {$[\mathrm{M}+4]^{+}$} \\
\hline & trans-Nonachlor & 406.7870 & {$[\mathrm{M}+2]^{+}$} & 408.7841 & {$[\mathrm{M}+4]^{+}$} \\
\hline & ${ }^{13} C_{10}$-trans-Nonachlor & 416.8205 & {$[\mathrm{M}+2]^{+}$} & 418.8175 & {$[\mathrm{M}+4]^{+}$} \\
\hline \multirow{6}{*}{$\begin{array}{l}\text { Group } 4 \\
(24.25-25.0)\end{array}$} & $\mathrm{o}, \mathrm{p}^{\prime}-\mathrm{DDD}$ & 235.0081 & {$[\mathrm{M}]^{+}$} & 237.0053 & {$[\mathrm{M}+2]^{+}$} \\
\hline & ${ }^{13} \mathrm{C}_{12}-\mathrm{o}, \mathrm{p}^{\prime}-\mathrm{DDD}$ & 235.0081 & {$[\mathrm{M}]^{+}$} & 237.0053 & {$[\mathrm{M}+2]^{+}$} \\
\hline & $\mathrm{p}, \mathrm{p}^{\prime}-\mathrm{DDE}$ & 246.0003 & {$[\mathrm{M}]^{+}$} & 247.9975 & {$[\mathrm{M}+2]^{+}$} \\
\hline & ${ }^{13} C_{12}-p, p^{\prime}-D D E$ & 258.0406 & {$[\mathrm{M}]^{+}$} & 260.0376 & {$[\mathrm{M}+2]^{+}$} \\
\hline & Dieldrin & 262.8570 & {$[\mathrm{M}+2]^{+}$} & 264.8541 & {$[\mathrm{M}+4]^{+}$} \\
\hline & ${ }^{13} \mathrm{C}_{12}$-Dieldrin & 269.8805 & {$[\mathrm{M}+2]^{+}$} & 271.8775 & {$[\mathrm{M}+4]^{+}$} \\
\hline \multirow{8}{*}{$\begin{array}{l}\text { Group } 5 \\
(25.0-26.0)\end{array}$} & Endrin & 262.8570 & {$[\mathrm{M}+2]^{+}$} & 264.8541 & {$[\mathrm{M}+4]^{+}$} \\
\hline & ${ }^{13} \mathrm{C}_{12}$-Endrin & 269.8805 & {$[\mathrm{M}+2]^{+}$} & 271.8775 & {$[\mathrm{M}+4]^{+}$} \\
\hline & $\mathrm{p}, \mathrm{p}^{\prime}-\mathrm{DDD}$ & 235.0081 & {$[\mathrm{M}]^{+}$} & 237.0053 & {$[\mathrm{M}+2]^{+}$} \\
\hline & ${ }^{13} C_{12}-p, p^{\prime}-D D D$ & 235.0081 & {$[\mathrm{M}]^{+}$} & 237.0053 & {$[\mathrm{M}+2]^{+}$} \\
\hline & $o, p^{\prime}-D D T$ & 235.0081 & {$[\mathrm{M}]^{+}$} & 237.0053 & {$[\mathrm{M}+2]^{+}$} \\
\hline & ${ }^{13} \mathrm{C}_{12}-\mathrm{o}, \mathrm{p}^{\prime}-\mathrm{DDT}$ & 235.0081 & {$[\mathrm{M}]^{+}$} & 237.0053 & {$[\mathrm{M}+2]^{+}$} \\
\hline & cis-Nonachlor & 406.7870 & {$[\mathrm{M}+2]^{+}$} & 408.7841 & {$[\mathrm{M}+4]^{+}$} \\
\hline & ${ }^{13} \mathrm{C}_{10}$-cis -Nonachlor & 416.8205 & {$[\mathrm{M}+2]^{+}$} & 418.8175 & {$[\mathrm{M}+4]^{+}$} \\
\hline \multirow{4}{*}{$\begin{array}{l}\text { Group } 6 \\
(26.0-33.0)\end{array}$} & $\mathrm{p}, \mathrm{p}^{\prime}-\mathrm{DDT}$ & 235.0081 & {$[\mathrm{M}]^{+}$} & 237.0053 & {$[\mathrm{M}+2]^{+}$} \\
\hline & ${ }^{13} C_{12}-p, p^{\prime}-D D T$ & 235.0081 & {$[\mathrm{M}]^{+}$} & 237.0053 & {$[\mathrm{M}+2]^{+}$} \\
\hline & Mirex & 271.8102 & {$[\mathrm{M}]^{+}$} & 273.8072 & {$[\mathrm{M}+2]^{+}$} \\
\hline & ${ }^{13} \mathrm{C}_{10}$-Mirex & 276.8269 & {$[\mathrm{M}]^{+}$} & 278.8240 & {$[\mathrm{M}+2]^{+}$} \\
\hline
\end{tabular}

Table 1. Accurate mass for selected monitoring ions, grouping retention times, and fragments 
The conventional gas chromatography-high resolution mass spectrometric conditions are as follows. The separation of organochlorine pesticides is carried out by using a DB-5MS capillary column (60 m height $\times 0.25 \mathrm{~mm}$ inner diameter $\times 0.25 \mu \mathrm{m}$ film thickness). A splitless injection $(1 \mu \mathrm{L})$ is used with an injector temperature of $260^{\circ} \mathrm{C}$. The oven is programmed from $100{ }^{\circ} \mathrm{C}(5$ min) to $280{ }^{\circ} \mathrm{C}$ with a ramp rate of $10^{\circ} \mathrm{C} / \mathrm{min}$ and then held at $280^{\circ} \mathrm{C}$ for $10 \mathrm{~min}$. The transfer line and source temperatures are $280{ }^{\circ} \mathrm{C}$ in the electron impact mode. The resolution is maintained over 10,000 (10\% valley definition). The retention time is divided to collect data on 22 organochlorine pesticides in six groups. The accurate mass of the selected monitoring ions, grouping retention times, and fragments are shown in Table 1. The typical chromatograms of HCHs and DDEs in human serum are presented in Fig. 9.

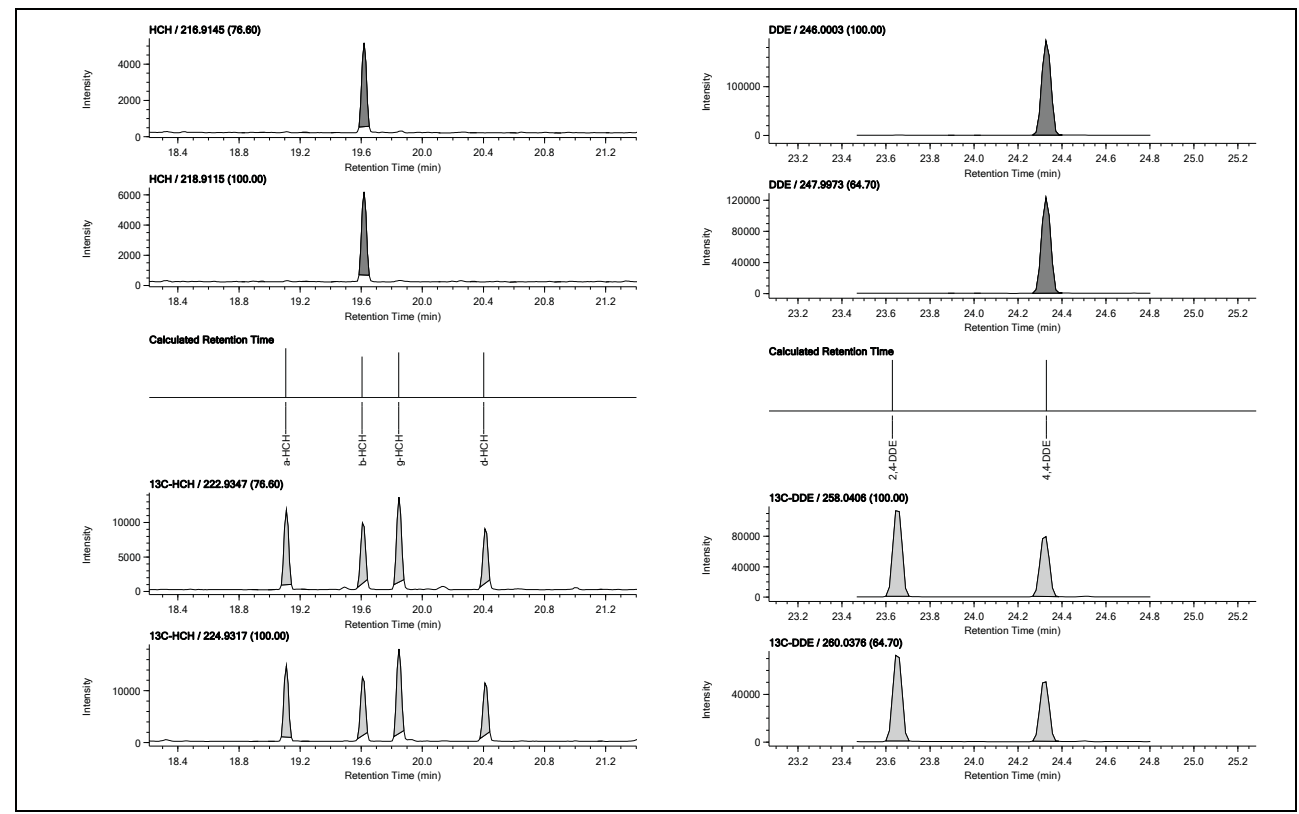

Fig. 9. Gas chromatography-high resolution mass spectrometric chromatograms of hexachlorcyclohexanes and dichlorodiphenyldichloroethylenes in human serum

\section{Organochlorine pesticides in human serum}

\subsection{Organochlorine pesticides in the general population}

Everybody has organochlorine pesticides in their body. Irrespective of age, gender, socioeconomic status, and country, these pesticides and their metabolites are detectable in blood or tissue, although the exposure levels differ according to various factors. Reported data on the levels of organochlorine pesticides in human serum are summarized in Table 2. It is difficult to compare these results directly because of the different periods of survey, ranging from 1959 to 2006 . However, the serum levels of these chemicals in the general population have been decreasing over time, after the periods of their peak production and use. The most abundant residue in the general population is $p, p^{\prime}$-DDE (Table 2); its median 
serum concentration is much higher in the Chinese general population than in the United States, European, and other Asian populations in the same sampling year. The serum concentrations of these pesticides show regional differences because of regional variations in their use and different times of discontinuation.

Human exposure to organochlorine pesticides is primarily through the diet. The dietary main source is fatty food, such as meat, fish, poultry, and dairy products. Continuous exposure primarily occurs through the food supply, even if the produced foods within a country do not contain detectable residues, because food imported from other countries that still use organochlorine pesticides may be a source of human exposure. Exposure via inhalation of the ambient air is thought to be insignificant compared with dietary intake. Prenatal exposure to organochlorine pesticides is possible via the placenta. Breast feeding is the major source of infant exposure.

\subsection{Levels of organochlorine pesticides in the North American population}

The National Health and Nutrition Examination Survey (NHANES), conducted by the CDC's National Center for Health Statistics, is a program of studies designed to assess the health and nutritional status of adults and children in the United States. Of the part of the NHANES, organochlorine pesticides were measured in the 1999-2000, 2001-2002, and 20032004 surveys in a subsample of participants aged 20 years and older, who were selected as the representative sample of the United States population. The abundant organochlorine pesticides in serum were $p, p^{\prime}$-DDE, trans-nonachlor, oxychlordane, $\mathrm{HCB}$, and $\beta-\mathrm{HCH}$. In the NHANES 1999-2000 and 2001-2002, the median serum HCB concentrations were below the detection limit, and in the NHANES 2003-2004 survey, the median serum concentration was $14.9 \mathrm{ng} / \mathrm{g}$ lipid. The median concentration of $p, p^{\prime}$-DDE ranged from 203 to $250 \mathrm{ng} / \mathrm{g}$ lipid. The serum concentration of this compound was higher in Mexican-Americans than in nonHispanic blacks and whites. The median serum concentrations of trans-nonachlor ranged from 17.8 to $14.8 \mathrm{ng} / \mathrm{g}$ lipid between 1999 and 2004. The median concentrations of oxychlordane in 2001-2002 and 2003-2004 were 11.1 and $12.3 \mathrm{ng} / \mathrm{g}$ lipid, respectively. The median concentrations of $p, p^{\prime}$-DDT and $o, p^{\prime}$-DDT were below the detection limit in all these surveys. The median concentrations of aldrin, dieldrin, endrin, $\beta-\mathrm{HCH}, \gamma-\mathrm{HCH}$, heptachlor epoxide, and mirex were also below the limit of detection. The serum concentrations of $\mathrm{HCB}, \beta-\mathrm{HCH}, p, p^{\prime}$-DDE, oxychlordane, and trans-nonachlor increased with increasing age and were significantly higher in the 60 years and older age group (CDC, 2005; Patterson et al., 2009).

Because the general population was exposed to these pesticides by eating contaminated fatty food such as fish, an Inuit population in Greenland showed high levels of exposure (Rusiecki et al., 2008). Serum samples were collected from 70 Greenlandic Inuit (61 men, 9 women) under the Arctic Monitoring and Assessment Program (AMAP) in 1997-1998. Their age of the subject ranged from 19 to 67 years. The median concentrations of $p, p^{\prime}$-DDT, $p, p^{\prime}-$ $\mathrm{DDE}, \beta-\mathrm{HCH}, \mathrm{HCB}$, trans-chlordane, oxychlordane, and mirex were $25.1,1268,40.0,239,883$, 249 , and $38.9 \mathrm{ng} / \mathrm{g}$ lipid, respectively. Compared with the other populations and three National Health and Nutrition Examination Survey results, the serum organochlorine pesticide levels in Greenland Inuit are relatively high and the $p, p^{\prime}$-DDE and $\beta-\mathrm{HCH}$ levels rank among the highest worldwide. 
The National Health and Nutrition Examination Survey biomonitoring study show the current levels of organochlorine pesticides in the general population of the United States, while a longitudinal cohort study reveal the past exposure levels. The Child Health and Development Studies (CHDS) established a longitudinal cohort of 20,754 pregnant women enrolled in the San Francisco Bay Area Kaiser Foundation Health plan between 1959 and 1967 (Bhatia et al., 2005). During this period, DDT was produced and used in the United States (banned since 1972). Of the cohort, 283 maternal serum samples were randomly selected for DDT and DDE analysis. The median serum concentrations of $p, p^{\prime}$-DDE and $p, p^{\prime}-$ DDT in maternal serum were 5200 and $1400 \mathrm{ng} / \mathrm{g}$ lipid, respectively. James et al. (2002) measured the serum concentrations of $p, p^{\prime}$-DDT, $p, p^{\prime}$-DDE, $o, p^{\prime}$-DDT, $o, p^{\prime}$-DDE, and heptachlor epoxide in pregnant women participating in the Child Health and Development Study (CHDS), conducted during 1963-1967, which was the time of peak usage and production of these organochlorine pesticides (James et al., 2002). The median concentrations of $p, p^{\prime}$-DDE and $p, p^{\prime}$-DDT were 5878 and $1611 \mathrm{ng} / \mathrm{g}$ lipid, respectively. The serum from the women of this cohort showed higher organochlorine pesticide concentrations than those of the recent general population samples. The serum concentration of $p, p^{\prime}$-DDE and $p, p^{\prime}$-DDT in the United States dramatically decreased over the period between 1950s and 2000s. The concentrations of $p, p^{\prime}$-DDE were comparable in the Child Health and Development Study and in Chinese women from Shanghai in 1996-1998, whereas the concentration of $p, p^{\prime}$-DDT was much higher than that in the Chinese women (Lee et al., 2007b).

\subsection{Levels of organochlorine pesticides in the general Asian population \\ 4.3.1 China}

Currently, the general Chinese population shows one of the highest organochlorine pesticide residues in their body, indicating recent heavy use of these pesticides. The serum samples of 250 Chinese women from Shanghai were collected in 1996-1998 as part of a population-based case-control study on breast cancer (Lee et al., 2007b). The median serum concentrations of $\beta-\mathrm{HCH}, p, p^{\prime}$-DDT, $p, p^{\prime}$-DDE, and $\mathrm{HCB}$, measured by gas chromatography with an electron capture detector, were 5065, 309, 7635, and $62.7 \mathrm{ng} / \mathrm{g}$ lipid, respectively. The serum concentrations of $\beta-\mathrm{HCH}$ and $p, p^{\prime}$-DDE among these women were much higher than those observed in other general populations in the same year. To assess the exposure to persistent organic pollutants in south China, serum samples were collected from the inhabitants of Guiyu and Haojiang, Guangdon Province, in 2005 and analyzed for 12 organochlorine pesticides by using gas chromatography and mass spectrometry in electron impact and selected ion monitoring modes (Bi et al., 2007). The $p, p^{\prime}$-DDE concentrations ranged from 81 to $1500 \mathrm{ng} / \mathrm{g}$ lipid (median concentration of $540 \mathrm{ng} / \mathrm{g}$ lipid) in Guiyu and from 320 to $3900 \mathrm{ng} / \mathrm{g}$ lipid (median concentration of $1800 \mathrm{ng} / \mathrm{g}$ lipid) in Haojiang. The median $\mathrm{HCH}$ and DDT concentrations in Haojiang were three times higher than those in Guiyu although these cities are only about $50 \mathrm{~km}$ apart; the main industry of Guiyu is ewaste recycling and that of Haojiang is fishing. Guiyu showed one of the highest serum PBDE concentrations in the world. The general Chinese population has the highest concentrations of $p, p^{\prime}$-DDE, $p, p^{\prime}$-DDT, and $\beta-\mathrm{HCH}$ in their serum, suggesting that this population was heavily exposed to these pesticides, despite the fact that DDTs and HCHs have been banned in China. 


\subsubsection{Japan}

The background serum levels of organochlorine compounds were evaluated by determination of 8 PCDDs, 10 PCDDFs, 40 PCBs, and 13 organochlorine pesticides in Japanese women of reproductive age (Tsukino et al., 2006). The serum samples were obtained from of 80 Japanese women aged 26-43 years and then analyzed by isotope dilution gas chromatography and high resolution mass spectrometry at the CDC in the United States. The frequently detected organochlorine pesticides were $p, p^{\prime}$-DDE (median concentration of $221 \mathrm{ng} / \mathrm{g}$ lipid) followed by $\beta-\mathrm{HCH}$, trans-nonachlor, and oxychlordane. The median concentrations of $\mathrm{HCB}, \gamma-\mathrm{HCH}$, heptachlor epoxide, dieldrin, $o, p^{\prime}$-DDT, $p, p^{\prime}$ DDT, and mirex were below the limit of detection. The results of this study firstly revealed the median serum concentration of $p, p^{\prime}$-DDE in the general Japanese population. This concentration in serum was significantly and positively associated with fish intake. The geographic variation of serum organochlorine pesticide concentrations in Japan was studied by using serum samples obtained from the general population living in three locations (Miyako, Saku, and Nagono) in 1999 (Minh et al., 2006). The plasma samples were prepared by liquid liquid extraction, lipids were removed by a gel permeation chromatography and florisil column, and organochlorine pesticides were measured by gas chromatography with an electron capture detector. There were no significant regional differences in the concentrations of HCHs, DDTs, and HCB. On the other hand, chlordane compounds showed apparent geographic differences. Miyako had higher serum concentrations of chlordanes, suggesting historic use of chlordane pesticides for termite control.

Fukata et al. (2005) assessed fetal exposure to chlorine contaminants. In their study, 32 maternal serum and umbilical cord serum samples were collected from pregnant women who lived in Chiba and Yamanashi, near Tokyo, Japan in 2002-2003 (Fukata et al., 2005). Nineteen organochlorine pesticides were measured by using gas chromatography and mass spectrometry after liquid liquid extraction and a florisil cartridge cleanup. The highest concentrations found in maternal serum were $p, p^{\prime}$-DDE (median concentration of $93 \mathrm{ng} / \mathrm{g}$ lipid), which was the lowest level of this compound among other studies on the general Japan population. The median concentrations of $\mathrm{HCB}, \mathrm{HCHs}, p, p^{\prime}$-DDT, oxychlordane, and trans-nonchlor were $16,26,2.4,1.2$, and $7.0 \mathrm{ng} / \mathrm{g}$ lipid, respectively, with a detection rate over $80 \%$. The median concentrations of $p, p^{\prime}$-DDE and HCB in maternal serum were higher than those in cord serum. This study found a strong correlation between maternal serum and cord serum for some organochlorine pesticides such as $\mathrm{HCB}, \mathrm{HCHs}$, and heptachlor epoxide, which showed a correlation coefficient over 0.72; in particular, maternal serum showed higher organochlorine pesticide concentrations than cord serum.

Masuda et al. (2005) collected 152 blood samples from residents aged 20-60 years in Fukuoka in 1999 (Masuda et al., 2005). The serum samples were extracted with acetone/hexane and the lipid was removed by gel permeation chromatography. The samples were analyzed for $\mathrm{HCB}, p, p^{\prime}$-DDE, $p, p^{\prime}$-DDT, $p, p^{\prime}$-DDD, $\beta$ - $\mathrm{HCH}$, dieldrin, transnonachlor, cis-nonachlor, heptachlor epoxide, trans-chlordane, cis-chlordane, and oxychlordane by using gas chromatography-high resolution mass spectrometry. ${ }^{13} \mathrm{C}$-labeled internal standards for organochlorine pesticides were not used in this study. All the pesticides analyzed were detected in serum samples. The median serum concentrations of $\mathrm{HCB}, \beta-\mathrm{HCH}$, dieldrin, $p, p^{\prime}$-DDE, $p, p^{\prime}$-DDT, trans-nonachlor, and oxychlordane were over 10 $\mathrm{ng} / \mathrm{g}$ lipid, whereas those of heptachlor epoxide, $p, p^{\prime}$-DDD, trans-chlordane, cis-chlordane, 
and cis-nonachlor were lower than $10 \mathrm{ng} / \mathrm{g}$ lipid. The most abundant compound was $p, p^{\prime}-$ DDE (median concentration of $312 \mathrm{ng} / \mathrm{g}$ lipid) followed by $\beta-\mathrm{HCH}$ (median concentration of $280 \mathrm{ng} / \mathrm{g}$ lipid), which was the highest levels in Table 2, except for the Chinese samples from Shanghai.

Takasuka et al. (2004a) studied biological elimination of persistent organic pollutants in humans via intake of fermented brown rice with Aspergillus oryzae (Takasuga et al., 2004a). After two years of consumption, those who ate the fermented brown rice had greater elimination of PCDD/Fs than those who did not, although the former group showed slightly higher serum PBDE concentrations (Takasuga et al., 2004b). In 18 serum samples from nine couples aged 37-48 years in Japan, selected organochlorine pesticides were identified by gas chromatography-high resolution mass spectrometry to assess the impact of intake of fermented brown rice with Aspergillus oryzae on biological elimination of organochlorine pesticides (Takasuga et al., 2006). This paper reported total DDT, total $\mathrm{HCH}$, total chlordane, and HCB concentrations of 230, 53, 36.5, and $13.5 \mathrm{ng} / \mathrm{g}$ lipid, respectively. Those who ate the fermented brown rice (7.5-10.5 g after their meal) for two years did not show reduced serum concentrations of DDTs, $\mathrm{HCHs}$, and chlordanes.

\subsubsection{Korea}

Kang et al. (2008) reported the first investigation on the levels of organochlorine pesticides in human serum samples from urban areas in Korea (Kang et al., 2008). The serum samples were obtained from 40 subjects who participated in the Health Assessment Study of Seoul Citizens related to municipal solid waste incinerators and lived in three areas (Kangnam, Nowon, and Yangchun) in Seoul. The participants consisted of 20 males and 20 females (age range 27-58 years, mean age $=45$ ). The serum samples were extracted on $\mathrm{C}_{18}$ solid-phase extraction cartridges and then applied to silica gel/florisil solid-phase extraction cartridges for cleanup. The concentrations of organochlorine pesticides and PCBs were measured by isotope dilution gas chromatography-high resolution mass spectrometry, which gave accurate and precise data for investigations of trend and international comparisons. Among the 22 investigated organochlorine pesticides, $p, p^{\prime}-\mathrm{DDE}, \beta-\mathrm{HCH}, p, p^{\prime}-\mathrm{DDT}, \mathrm{HCB}$, and transnonachlor were frequently detected in all samples. The most abundant pesticide was $p, p^{\prime}-$ $\mathrm{DDE}$, having a median concentration of $224 \mathrm{ng} / \mathrm{g}$ lipid. The median serum concentrations of $\beta-\mathrm{HCH}, p, p^{\prime}$-DDT, and HCB were higher than $10 \mathrm{ng} / \mathrm{g}$ lipid, whereas trans-nonachlor, heptachlor epoxide, oxychlordane, and $p, p^{\prime}$-DDD had median concentrations below $10 \mathrm{ng} / \mathrm{g}$ lipid. The correlation coefficients between PCBs and organochlorine pesticides ranged from 0.365 to 0.906 , with the highest correlation found between PCB153 and trans-nonachlor $(r=$ 0.906). The organochlorine pesticides were also positively correlated to each other. Strong correlations between serum concentrations of organochlorine pollutants suggest that humans are exposed to PCBs and organochlorine pesticides via similar routes, because they were both widely used in the same period. In studies conducted within the Chinese population, extremely high concentrations of organochlorine pesticides contrasted with very low concentrations of PCBs (Lee et al., 2007b). A community-based health survey was performed in 2006 in Uljin (Son et al., 2010). Uljin is a geographically small county located on the east coast of Korea. Among 1007 participants, 40 subjects with diabetes and 40 controls matched for sex and age were selected. The most abundant organochlorine pesticide was $p, p^{\prime}$-DDE, 
followed by $\beta-\mathrm{HCH}, p, p^{\prime}$-DDT, trans-nonachlor, $\mathrm{HCB}$, oxychlordane, and heptachlor epoxide among the 22 organochlorine pesticides analyzed. The total organochlorine pesticide concentrations ranged from 38.8 to $4598 \mathrm{ng} / \mathrm{g}$ lipid, with the mean and median concentrations of total organochlorine pesticides being 638 and $483 \mathrm{ng} / \mathrm{g}$ lipid, respectively. In addition, when the concentratons of organochlorine pesticides were compared between Seoul and Uljin, regional differences were found.

\subsubsection{New Zealand}

The serum samples were obtained from the New Zealand population aged 15 years and older during 1996-1997 (Bates et al., 2004). This is the first persistent organochlorine biomonitoring study in the adult population of an entire country, and the 60 serum samples were pooled according to stratification criteria by using 1834 individual serum samples. The aim of the study was to estimate the baseline concentration of organochlorine pesticides in serum among the general New Zealand population. Organochlorine pesticides were extracted by using a $\mathrm{C}_{18}$ solid-phase extraction cartridge and purified by a florisil cartridge. Target analytes were quantified by isotope dilution gas chlormatography-high resolution mass spectrometry operating in the selected ion monitoring mode. The frequently detected pesticides were $p, p^{\prime}$-DDE, $\beta$-HCH, dieldrin, $p, p^{\prime}$-DDT, $\mathrm{HCB}$, and trans-nonachlor, but aldrin, endrin, heptachlor epoxide, oxychlordane, and mirex were not detected in the pooled serum. The median concentrations of $p, p^{\prime}$-DDE and $\beta-\mathrm{HCH}$ were 919 and $10.7 \mathrm{ng} / \mathrm{g}$ lipid, respectively. The $p, p^{\prime}$-DDE concentration showed an increasing trend from the north to the south regions, reflecting historical patterns of DDT use. In this study, dieldrin was frequently detected, with a median concentration of $11.5 \mathrm{ng} / \mathrm{g}$ lipid. The use of DDT and dieldrin in agriculture was banned in the 1970s. The serum concentrations of pesticides increased with age. The concentrations of $p, p^{\prime}$-DDE, $\beta-\mathrm{HCH}$, and dieldrin were significantly higher in the group aged over 50 years than in the younger age group. The median $p, p^{\prime}$-DDE concentration of these subjects was lower than that of subjects from China (Bi et al., 2007), Romania (Dirtu et al., 2006), and Slovakia (Petrik et al., 2006). However, the median concentration of this compound in the New Zealand population was higher than that in subjects from Korea (Kang et al., 2008), Japan (Tsukino et al., 2006), the United Kingdom (Thomas et al., 2006), and the United States (CDC, 2005).

\subsection{Levels in the European population \\ 4.4.1 Sweden}

In a population-based case-control study of organochlorines and endometrial cancer risk, the serum concentrations of five organochlorine pesticides in elderly women in Sweden were reported to evaluate associations between serum concentrations of organochlorines and lifestyle or medical characteristics of Swedish women (Glynn et al., 2003). The 205 women aged 50-74 years old were participated as controls from 12 Swedish counties on the coasts of the Gulf of Bothnia, the Baltic Sea, and the largest Swedish lakes in 1996-1997. The frequently detected organochlorine pesticides, $p, p^{\prime}-\mathrm{DDE}, \mathrm{HCB}, \beta-\mathrm{HCH}$, and trans-nonachlor, and oxychlordane, were analyzed on gas chromatography with an electron capture detector. The most abundant pesticide was $p, p^{\prime}$-DDE with the median concentration of $497 \mathrm{ng} / \mathrm{g}$ lipid. The other pesticides had median concentrations below $10 \mathrm{ng} / \mathrm{g}$ lipids. Correlation analysis 
showed that the concentrations of chlorinated pesticides and their metabolites were positively correlated with each other $(r=0.48-0.89)$. High correlation was found between oxychlordane and trans-nonachlor. Age was a significant determinant of serum concentration of chlorinated pesticides in this study. Glynn et al. (2007) also reported another serum concentration of the general Swedish population (Glynn et al., 2007). The serum of 323 pregnant primiparous women living in Uppsala county (age 18-41 years) sampled in 1996-1999. Organochlorine pesticides and their metabolites were analysed by gas chromatography with an electron capture detector. Concentrations of $\alpha-\mathrm{HCH}, \gamma-\mathrm{HCH}$, oxychlordane, $o, p^{\prime}$-DDT, $o, p^{\prime}$-DDT, $p, p^{\prime}$-DDT, and $p, p^{\prime}$-DDD were below the limit of quantification, indicating no recent exposure to technical mixtures of these pesticides. Median concentrations of $\beta-\mathrm{HCH}, \mathrm{HCB}$, trans-nonachlor and $p, p^{\prime}-\mathrm{DDE}$ were $9,23,5$, and 88 $\mathrm{ng} / \mathrm{g}$ lipid, respectively. Compared to previous study, median concentration of $p, p^{\prime}$-DDE was extremely different. It could be explained that different consumption patterns of fish. More than half of the women reported they did not eat fish from the Baltic Sea in this study. Regression analysis showed that women born in the Nordic region had higher concentrations of $\beta-\mathrm{HCH}$ and $p, p^{\prime}$-DDE compared to the non-Nordic region. Concentrations of $\beta-\mathrm{HCH}, \mathrm{HCB}$, trans-nonachlor and $p, p^{\prime}$-DDE were also increased with increasing age and positively associated with consumption of fatty fish during adolescence.

\subsubsection{United Kingdom}

The serum was collected from 154 volunteers aged 22 to 80 from 13 UK cities and towns in 2003 (Thomas et al., 2006). Because the serum extract was cleaned using concentrated sulfuric acid, 12 organochlorine pesticides were analyzed by gas chromatography and mass spectrometry (trans-chlordane and cis-chlordane, $\mathrm{HCB}$, six DDT analogues, $\alpha-\mathrm{HCH}, \beta-\mathrm{HCH}$, and $\gamma-\mathrm{HCH}$ ). The median concentrations of $\mathrm{HCB}, \beta-\mathrm{HCH}$, and $p, p^{\prime}$-DDE were 11, 12, and 100 $\mathrm{ng} / \mathrm{g}$ lipid, respectively. The concentration of $p, p^{\prime}$-DDE showed relatively wide range from 15 to $2600 \mathrm{ng} / \mathrm{g}$ lipid. The median concentrations of $p, p^{\prime}$-DDE in UK was lower than those found in Belgium (Covaci et al., 2002; Koppen et al., 2002), the United States (CDC, 2005), and similar to Sweden (Glynn et al., 2003). $\beta-\mathrm{HCH}$ and $p, p^{\prime}$-DDE concentration also showed that significant and positive correlation with age.

\subsubsection{Spain}

The 682 serum samples of the Spanish population from the Canary Islands was collected in 1998 (Zumbado et al., 2005). The study subjects aged between 6 and 75 years and lived in the Canary Islands, where are extensive farming areas and compose of seven islands. Investigated organochlorine pesticides were determined by gas chromatography with an electron capture detector. Of the DDT analogues, $p, p^{\prime}$-DDE, $p, p^{\prime}$-DDD, $p, p^{\prime}$-DDT, $o, p^{\prime}$-DDE, $\mathrm{o}, \mathrm{p}^{\prime}$-DDD, and $o, p^{\prime}$-DDT were detected in the serum samples. Even technical DDT prohibited nowadays, $o, p^{\prime}$-DDT and $p, p^{\prime}$-DDT were frequently present in $40 \%$ of the samples. The median concentrations of $p, p^{\prime}$-DDE was $118 \mathrm{ng} / \mathrm{g}$ lipid, while the total DDT serum concentration was $380 \mathrm{ng} / \mathrm{g}$ lipid. Of the seven islands (Gran Canaria, Lanzarote, Fuerteventura, Tenerife, La Palma, La Gomera, and El Hierro), median serum concentrations of $o, p^{\prime}$-DDT and $p, p^{\prime}$-DDT from Gran Canaria showed 250 and $233 \mathrm{ng} / \mathrm{g}$ lipid, respectively, while the median concentrations of those compounds from the other 
regions were not detected over limit of the detection. However, serum concentration of $p, p^{\prime}-$ DDE showed between 94 and $140 \mathrm{ng} / \mathrm{g}$ lipid, which is consistent according to the islands. Luzardo et al. (2006) reported the serum concentrations of lindane and cyclodienes (aldrin, dieldrin and endrin) in the young population of the Canary Islands (Luzardo et al., 2006). Lindane, aldrin, and endrin were detected with the detection frequency of over $50 \%$ of the samples and the median concentrations were $69,9,54.5$, and $34.9 \mathrm{ng} / \mathrm{g}$ lipid, respectively. Endrin was the most frequently detected cyclodienes $(72 \%)$, and dieldrin has $27 \%$ of detection rate in this population. Even this study reported for the first time the presence of cyclodiene and lindane in a Spanish population, lindane, aldrin, and endrin were not commonly detected pesticides in other previous studies. The serum of 72 women living in El Ejido and Granada in Spain were collected and the subjects aged from 18 to 35 years (Jimenez Torres et al., 2006). At the same time their adipose tissue and umbilical cord blood were also collected during giving birth by caesarean section to establish a correlation in organochlorine compounds between these biological compartments. The serum mean concentrations of lindane and HCB were 1.3 and $20.1 \mathrm{ng} / \mathrm{mL}$ serum. The serum mean concentrations of $p, p^{\prime}$-DDE, $p, p^{\prime}$-DDD, and $p, p^{\prime}$-DDT were $31.9,44.5$, and $10.5 \mathrm{ng} / \mathrm{ml}$ serum, respectively. The most abundant contaminated pesticides were endosulfan II, followed by $p, p^{\prime}$-DDE. The concentration of $p, p^{\prime}$-DDE in between maternal serum and umbilical cord serum was significantly different $(p<0.001)$. Of the EPIC (European Prospective Investigation into Cancer and Nutrition) Spain cohort, serum samples consisted of 953 subjects aged 35-64 years old from five Spanish regions during 1992-1996 (Jakszyn et al., 2009). The serum were analyzed using gas chromatography with an electron capture detector to quantify $\beta-\mathrm{HCH}, \mathrm{HCB}, p, p^{\prime}-\mathrm{DDE}$, and $p, p^{\prime}$-DDT. The median concentrations of $\beta$ $\mathrm{HCH}, \mathrm{HCB}, p, p^{\prime}$-DDE were 221, 462, and $857 \mathrm{ng} / \mathrm{g}$ lipid, respectively. Increasing level of $p, p^{\prime}$-DDE and $\beta-\mathrm{HCH}$ to southern region in the Mediterranean coast at the south of Spin, while level of HCB increasing to the north region. After adjusting by age, gender, region, body mass index (BMI), and sampling year, serum concentrations of organochlorine pesticides were not associated with any dietary consumption patterns.

\subsubsection{Denmark}

The Faroese birth cohort consisted of 1022 children in the Faroese islands during 1986-1987, which have been carried to characterize the adverse effects of seafood contamination and assess the prenatal exposure of the contaminants (Barr et al., 2006). Serum samples were analyzed for PCBs and $p, p^{\prime}$-DDE at delivrating time and age 14 years. The median serum concentration of $p, p^{\prime}$-DDE for the cord blood was $71 \mathrm{ng} / \mathrm{g}$ lipid, and for 14 years old children was $467 \mathrm{ng} / \mathrm{g}$ lipid. The concentrations of $p, p^{\prime}$-DDE in umbilical cord and children at age 14 showed significantly different concentrations, which were increased by age. The correlation analysis by the pearson correlation coefficients showed that the $p, p^{\prime}$-DDE was highly correlated with highly chlorinated PCB congener, PCB 180.

\subsubsection{Belgium}

Of the Flemish Environment and Health Study (FLEHS), serum samples were obtained from 200 Flemish women living in Antwerp (urban area) and Peer (rural area) in 1999 (Koppen et al., 2002). The 47 pooled serum samples were made by mixing of individual serum sample. 
The pooling categorized by ranking the women in the order of four criteria; decreasing daily intake of meat and fish, decreasing daily intake of eggs and milk, increasing total number of weeks of lactation and increasing BMI. The pooled serum samples were spiked with internal standard and added with formic acid. The mixtures were subjected to extraction using solidphase extraction cartridge, followed by cleanup on acidified silica gel cartridge. HCB, $p, p^{\prime}-$ DDT, $p, p^{\prime}$-DDE, and $\gamma-\mathrm{HCH}$ were measured using gas chromatography and mass spectrometry. The median concentrations of $\mathrm{HCB}, p, p^{\prime}$-DDT, $p, p^{\prime}$-DDE, and $\gamma$-HCH were $109.9,2.6,871.3$ and $5.7 \mathrm{ng} / \mathrm{g}$ lipid, respectively. Concentrations of $p, p^{\prime}$-DDE, and $\gamma-\mathrm{HCH}$ were higher in rural region (Peer). As the use of DDT has been banned more than 30 years ago, concentrations of $p, p^{\prime}$-DDT were significantly higher in Peer. HCB was significantly higher in urban area (Antwerp). This study reported $\gamma-\mathrm{HCH}$ concentration in serum samples.

\section{Effects of organochlorine pesticides on human health}

Most organochlorine pesticides are known to be endocrine disruptors, neurotoxicants, and carcinogens. Their presence in the general population at the current background levels does not mean that they will result in direct adverse health effects, but they can cause disorders in the human body. As the human health effects of these chemicals are inconsistent in epidemiologic research, it is still debatable whether such exposure affects human health (Kaiser, 2000; Snedeker, 2001). This section focuses on the human health disorders associated with organochlorine pesticides. To investigate their potential health risks upon exposure, biomonitoring of organochlorine pesticides in human serum is essential. General toxicological and environmental data on hazardous substances are compiled in toxicological profiles published by the Agency for Toxic Substances and Disease Registry (ATSDR). On the basis of these data, the agency derives chemical-specific minimal risk levels (MRLs) that assist in evaluating public health risks associated with exposure.

\subsection{Thyroid hormonal imbalance}

Most organochlorine pesticides and organochlorines may cause thyroid hormonal inactivity. Thyroid hormone is produced by the thyroid gland, and its major forms are thyroxine $\left(\mathrm{T}_{4}\right)$ and triiodothyronine $\left(\mathrm{T}_{3}\right)$. An imbalance of thyroid hormeones can lead to various disorders. In 385 adult men, the serum concentrations of $p, p^{\prime}$-DDE and HCB were found to be associated with thyroid hormone levels (Meeker et al., 2007). The former compound was associated with increased free thyroxine $\left(\mathrm{T}_{4}\right)$ and total triiodothyronine $\left(\mathrm{T}_{3}\right)$ levels, and inversely assosiated with thyroid-stimulating hormone (TSH). Hagmar et al. (2001) reported no associations between $p, p^{\prime}$-DDE and thyroid hormones (Hagmar et al., 2001). Turyk et al. (2006) studied associations of total $\mathrm{T}_{4}$ and TSH with organochlorines including $p, p^{\prime}$-DDE using the National Health and Nutrition Examination Survey 1999-2000 data (Turyk et al., 2006). They found inverse associations of total $T_{4}$ with exposure to dioxin-like organochlorines, stronger associations in females, and a dose-dependent decrease in total $\mathrm{T}_{4}$ with exposure to dioxin-like organochlorines at levels similar to those found in the general United States population. $\mathrm{T}_{4}$ was positively associated with $p, p^{\prime}$-DDE in all women but was negatively associated with this compound in men. Associations of thyroid-stimulating 
hormone (TSH) with $p, p^{\prime}$-DDE were insignificant and inconsistent (Turyk et al., 2007). A number of factors are related to the inconsistent human findings, including different detection methods as well as differences in age, gender, and other lifestyle factors.

\subsection{Hormone-related cancers: breast and prostate cancers}

Organochlorine pesticides may be associated with increased risk of hormone-related cancers including breast and prostate cancers. However, epidemiologic evidence is limited and inconsistent (Snedeker, 2001). Wolff et al. (1993) analyzed associations of serum $p, p^{\prime}$-DDE concentrations with the risk of breast cancer (Wolff et al., 1993). During 1985-1991, cases (n $=58)$ and controls $(n=171)$ enrolled in the New York University Women's Health Study (NYUWHS), a prospective cohort study of hormones, diet, and cancer. The mean levels of $p, p^{\prime}$-DDE were higher in patients with breast cancer than in control subjects. There were strong positive relationships between breast cancer risk and serum $p, p^{\prime}$-DDE levels. On the other hand, the authors did not find associations of the risk of breast cancer with serum $p, p^{\prime}-$ DDE concentrations in a similar prospective investigation of the New York University Women's Health Study (NYUWHS) during the period 1987-1992 (Wolff et al., 2000). Cases $(n=148)$ and individually matched controls $(n=295)$ had similar serum levels of this compound, providing no evidence for an association of breast cancer risk with $p, p^{\prime}$-DDE in blood. Recently, a case-control study was carreid out to investigate the association between breast cancer risk and organochlorines in Japanese women, which is the first large-scale study of an Asian population (Itoh et al., 2009). The serum samples were collected from Nagano during 2001-2005 and consisted of 403 breast cancer cases and matched controls. Organochlorine pesticides and PCBs were measured by using isotope dilution gas chromatography-high resolution mass spectrometry. The serum concentrations of organochlorine pesticides were not associated with increased risk of breast cancer in the Japanese population.

Xu et al. (2010) used the National Health and Nutrition Examination Survey 1999-2004 data to examine associations between serum concentrations of organochlorine pesticides and prostate and breast cancers (Xu et al., 2010). After adjustment for other covariates, the serum concentrations of $\beta-\mathrm{HCH}$, trans-nonachlor, and dieldrin were significantly associated with prostate cancer prevalence. However, there was no positive association between these serum concentrations and the risk of prevalent breast cancer. The Japan Public Health Center (JPHC) prospective study consisted of 14,203 men aged 40-69 years who participated from 1990 to 2005 (Sawada et al., 2010). From the cohort, 201 prostate cancer cases and two matched controls were compared for the median concentrations of organochlorine pesticides and PCBs. The odds ratios (ORs) and 95\% confidence intervals (CIs) for prostate cancer were estimated in relation to serum levels of $p, p^{\prime}$-DDT, HCB, $\beta-\mathrm{HCH}$, transnonachlor, oxychlordane, and mirex. No significant differences in the median levels of these pesticides were found between the cases and the controls. Further, no statistically significant association with total prostate cancer was seen with any organochlorine, suggesting the lack of an overall association between prostate cancer and organochlorine pesticides at the levels measured in the Japan Public Health Center population.

\subsection{Childhood developmental disorders}

As organochlorine pesticides are present in both cord blood and breast milk, fetuses and infants can be exposed to these chemicals during the prenatal and postnatal periods. Fetuses 
and infants are more vulnerable to neurotoxic environmental chemicals even at very lowlevel exposure, which can affect brain development, decrease cognitive function, and result in development disorders in childhood. Lee et al. (2007a) investigated learning disability (LD) and attention deficit disorder (ADD) in children aged 4-15 years from the National Health and Nutrition Examination Survey 1999-2000 data (Lee et al., 2007a). Dioxins in children showed significant positive associations with learning disability (LD), but $p, p^{\prime}$-DDE and trans-nonachlor were not associated with the prevalence of learning disability (LD). $\beta$ $\mathrm{HCH}$ was inversely associated with learning disability (LD) but not significantly. Sagiv et al. (2010) found higher risk for attention deficit hyperactivity disorder (ADHD) at higher levels of PCBs and $p, p^{\prime}$-DDE in a longitudinal cohort study including 788 mother-infant pairs (Sagiv et al., 2010). The PCB and $p, p^{\prime}$-DDE levels in cord serum were moderately associated with attention deficit hyperactivity disorder (ADHD) in children aged 7-11 years born in 1993-1998 in a PCB-contaminated area (ORs $=1.76)$. These results support the view that low-level prenatal organochlorine exposure is associated with attention deficit hyperactivity disorder (ADHD)-like behaviors in childhood. During 2001-2005, women of reproductive age in Mexico provided blood samples, and after birth, each child was checked for cognitive and psychomotor development. Among 244 mother-child pairs, $p, p^{\prime}$-DDE levels in the first trimester of pregancy were significantly and negatively associated with the psychomotor development index (PDI) of the children (Torres-Sánchez et al., 2007). No significant association was found between $p, p^{\prime}$-DDE levels and childhood neurodevelopment during the second or third trimester. Torres-Sánchez et al. (2009) also reported that the associations between prenatal exposure to $p, p^{\prime}$-DDE in cord serum and neurodevelopment disappeared after 12 months of infant age (Torres-Sánchez et al., 2009).

\subsection{Diabetes}

The prevalence of diabetes has been increasing globally over the past few decades (King et al., 1998). Recent epidemiologic studies have shown that background exposure to persistent organic pollutants, especially organochlorine pesticides, is strongly associated with type 2 diabetes. Lee et al. (2006) demonstrated a very strong relationship between the levels of persistent organic pollutants in serum, particularly oxychlordane and transnonachlor, and the risk of type 2 diabetes in the general American population by extensive analysis of the National Health and Nutrition Examination Survey 1999-2002 data (Lee et al., 2006). This association was higher in obese people than among the nonobese. The associations between the serum concentrations of organochlorine pesticides and the prevalence of diabetes were examined in the Mexican-American population (Cox et al., 2007) and Korean population (Son et al., 2010). Exposure of $p, p^{\prime}$-DDE was related to the incidence of diabetes in a cohort of Great Lakes sport fish consumers from 1994 to 2005 (Turyk et al., 2009). Lee et al. (2010) also investigated whether several persistent organic pollutants predict the risk of type 2 diabetes within the Coronary Artery Risk Development in Young Adults (CARDIA) cohort (Lee et al., 2010). Some persistent organic pollutants, such as trans-nonachlor and highly chlorinated PCBs, were associated with the incidence of type 2 diabetes over an 18-year period, especially in obese people. Persistent organic pollutants showed strong associations at relatively low exposures, resulting in inverted U-shaped dose-response curves instead of the traditional doseresponse relationship with diabetes. 


\begin{tabular}{|c|c|c|c|c|c|c|c|c|c|}
\hline Country & Year ${ }^{\mathrm{a}}$ & $\mathrm{n}$ & $\beta-\mathrm{HCH}$ & НСВ & Oxy & $\mathrm{TN}$ & DDE & DDT & reference \\
\hline Korea & 2006 & 40 & 49 & 16.7 & 4.8 & 6.5 & 224 & 18.6 & Kang et al., 2008 \\
\hline Korea & 2006 & 40 & 44 & 18.3 & 8.3 & 20.2 & 379 & 23.8 & Son et al., 2010 \\
\hline Japan & 2000 & 80 & 93.2 & $<\mathrm{LOD}$ & 9.0 & 20.9 & 221 & $<$ LOD & Tsukino et al., 2006b \\
\hline Japan & - & 18 & 50 & 13.5 & 7.3 & 21.9 & 218 & 11 & Takasuga et al., 2006 \\
\hline Japan & 1999 & 23 & $28^{\mathrm{b}}$ & 7.8 & $60^{c}$ & NA & $230^{\mathrm{d}}$ & NA & Minh et al., 2005 \\
\hline Japan & 1999 & 32 & $34^{\mathrm{b}}$ & 13 & $26^{c}$ & NA & $220^{\mathrm{d}}$ & NA & Minh et al., 2005 \\
\hline Japan & 1999 & 22 & $34^{b}$ & 9.8 & $28 \mathrm{c}$ & NA & $200^{d}$ & NA & Minh et al., 2005 \\
\hline Japan & 1999 & 152 & 280 & 21.6 & 13.8 & 50 & 312 & 28 & Masuda et al., 2005 \\
\hline Japan & 02-03 & 32 & $26^{\mathrm{b}}$ & 16.0 & 1.2 & 7.0 & 93 & 2.4 & Fukuta et al., 2005 \\
\hline Japan & 01-05 & 405 & 64 & 27 & 8.6 & 23 & 370 & 9.9 & Itoh et al., 2009 \\
\hline China & 2005 & 26 & $12^{\mathrm{b}}$ & 39 & NA & NA & $600^{\mathrm{d}}$ & NA & Bi et al., 2007 \\
\hline China & 2005 & 21 & $39 \mathrm{~b}$ & 31 & NA & NA & $2300^{d}$ & NA & Bi et al., 2007 \\
\hline China & $96-98$ & 250 & 5065 & 62.7 & NA & NA & 7635 & 309 & Lee et al., 2007b \\
\hline $\begin{array}{l}\text { New } \\
\text { Zealand }\end{array}$ & $96-97$ & $60^{\mathrm{f}}$ & 10.7 & $<\mathrm{LOD}$ & $<\mathrm{LOD}$ & $<\mathrm{LOD}$ & 919 & $<\mathrm{LOD}$ & Bates et al., 2004 \\
\hline Sweden & $96-97$ & 205 & 51 & 65 & 13 & 23 & 497 & NA & Glynn et al., 2003 \\
\hline Sweden & $96-99$ & 323 & 9 & 23 & $<$ LOD & 5 & 88 & $<\mathrm{LOD}$ & Glynn et al., 2007 \\
\hline UK & 2003 & 154 & 12 & 11 & NA & NA & 100 & 2.9 & Thomas et al., 2006 \\
\hline Spain & 1998 & 682 & NA & NA & NA & NA & 118 & $<$ LOD & Zumbado et al., 2005 \\
\hline Spain & $92-96$ & 953 & 221 & 462 & NA & NA & 858 & $<$ LOD & Jakszyn et al., 2009 \\
\hline Belgium & 1999 & $47^{\mathrm{f}}$ & $6.0^{\mathrm{e}}$ & 92.2 & NA & NA & 944.9 & 3.7 & Koppen et al., 2002 \\
\hline Romania & 2005 & 142 & 923 & 30 & & 4.0 & 1975 & 339 & Dirtu et al., 2006 \\
\hline Solvakia & 2001 & 1009 & 48.6 & 690 & NA & NA & 2521 & 72.9 & Petrik et al., 2006 \\
\hline Solvakia & 2001 & 1038 & 44.0 & 639 & NA & NA & 1368 & 33.2 & Petrik et al., 2006 \\
\hline USA & $99-00$ & 1702 & $<\mathrm{LOD}$ & $<\mathrm{LOD}$ & $<\mathrm{LOD}$ & 17.8 & 226 & $<\mathrm{LOD}$ & CDC, 2005 \\
\hline USA & 01-02 & 2307 & $<\mathrm{LOD}$ & $<$ LOD & 11.1 & 17.9 & 250 & $<$ LOD & CDC, 2005 \\
\hline USA & 03-04 & 1796 & $<\mathrm{LOD}$ & 14.9 & 10.3 & 14.8 & 203 & $<$ LOD & Patterson et al., 2009 \\
\hline USA & $97-98$ & 70 & 40 & 239 & 249 & NA & 1268 & 25 & Rusiecki et al., 2008 \\
\hline USA & $59-67$ & 283 & NA & NA & NA & NA & 5200 & 1400 & Bhatia et al., 2005 \\
\hline USA & $63-67$ & 399 & NA & NA & NA & NA & 5878 & 1611 & James et al., 2002 \\
\hline
\end{tabular}

aYear of collection; bsum of four hexachlorcyclohexane isomers; 'sum of $o, p^{\prime}$-DDT, $o, p^{\prime}$-DDD, $o, p^{\prime}$-DDE, $p, p^{\prime}$-DDT, $p, p^{\prime}$-DDD, and $p, p^{\prime}$-DDE; $\gamma$-HCH; f pooled serum

$\mathrm{NA}$, not available; LOD, limit of detection; $\mathrm{HCH}$, hexachlorcyclohexane; $\mathrm{HCB}$, hexachlorobenzene; Oxy, oxychlordane; TN, trans-nonachlor; DDE, $p, p^{\prime}$-dichlorodiphenyldichloroethylene; DDT, $p, p^{\prime}$ dichlorodiphenyltrichloroethane

Table 2. The median organochlorine pesticide concentrations (ng/g lipid) in serum samples of different countries 


\section{Conclusion}

Human biomonitoring data show that organochlorine pesticides are detectable in the body despite their ban a few decades ago. Nowadays, it is accepted that the general human population is exposed to background environmental levels of organochlorine pesticides. The exposure levels vary according to the region, population, and race, and have been decreasing over time. However, the current background concentrations of each these pesticides are still much higher than those of notorious organic pollutants such as PCDD/Fs, PCBs, and PBDEs. In addition, many epidemiologic studies have revealed that their current levels in the general human population are associated with several health disorders and may cause adverse effects on human health. In view of the number of factors related to the inconsistent human findings, including different detection and quantification methods, we recommend continuous biomonitoring study of organochlorine pesticides in human serum based on the analytical method using isotope dilution gas chromatography high resolution mass spectrometry.

\section{References}

Axmon, A., Rignell-Hydbom, A., 2006. Estimations of past male and female serum concentrations of biomarkers of persistent organochlorine pollutants and their impact on fecundability estimates. Environmental Research 101, 387-394.

Barr, D.B., Weihe, P., Davis, M.D., Needham, L.L., Grandjean, P., 2006. Serum polychlorinated biphenyl and organochlorine insecticide concentrations in a Faroese birth cohort. Chemosphere 62, 1167-1182.

Barr, J.R., Maggio, V.L., Barr, D.B., Turner, W.E., Sjodin, A., Sandau, C.D., Pirkle, J.L., Needham, L.L., Patterson, D.G., 2003. New high-resolution mass spectrometric approach for the measurement of polychlorinated biphenyls and organochlorine pesticides in human serum. Journal of Chromatography B 794, 137-148.

Bates, M.N., Buckland, S.J., Garrett, N., Ellis, H., Needham, L.L., Patterson, D.G., Turner, W.E., Russell, D.G., 2004. Persistent organochlorines in the serum of the nonoccupationally exposed New Zealand population. Chemosphere 54, 1431-1443.

Bhatia, R., Shiau, R., Petreas, M., Weintraub, J.M., Farhang, L., Eskenazi, B., 2005. Organochlorine pesticides and male genital anomalies in the child health and development studies. Environmental Health Perspectives 113, 220-224.

Bi, X., Thomas, G.O., Jones, K.C., Qu, W., Sheng, G., Martin, F.L., Fu, J., 2007. Exposure of electronics dismantling workers to polybrominated diphenyl ethers, polychlorinated biphenyls, and qrganochlorine pesticides in South China. Environmental Science and Technology 41, 5647-5653.

CDC, 2003. Laboratory Procedure Manual Method 28 for Second National Report on Human Exposure to Environmental Chemicals. Centers for Disease Contro and Prevention.

CDC, 2005. Third National Report on Human Exposure to Environmental Chemicals. Centers for Disease Control and Prevention, Washington, DC.

Conka, K., Drobna, B., Kocan, A., Petrik, J., 2005. Simple solid-phase extraction method for determination of polychlorinated biphenyls and selected organochlorine pesticides in human serum. Journal of Chromatography A 1084, 33-38. 
Covaci, A., Jorens, P., Jacquemyn, Y., Schepens, P., 2002. Distribution of PCBs and organochlorine pesticides in umbilical cord and maternal serum. The Science of The Total Environment 298, 45-53.

Cox, S., Niskar, A.S., Narayan, K.M., Marcus, M., 2007. Prevalence of self-reported diabetes and exposure to organochlorine pesticides among Mexican Americans: Hispanic health and nutrition examination survey, 1982-1984. Environmental Health Perspectives 115, 1747-1752.

Dirtu, A.C., Cernat, R., Dragan, D., Mocanu, R., Van Grieken, R., Neels, H., Covaci, A., 2006. Organohalogenated pollutants in human serum from Iassy, Romania and their relation with age and gender. Environment International 32, 797-803.

Focant, J.F., Sjodin, A., Turner, W.E., Patterson, D.G., 2004. Measurement of Selected Polybrominated Diphenyl Ethers, Polybrominated and Polychlorinated Biphenyls, and Organochlorine Pesticides in Human Serum and Milk Using Comprehensive Two-Dimensional Gas Chromatography Isotope Dilution Time-of-Flight Mass Spectrometry. pp. 6313-6320.

Fukata, H., Omori, M., Osada, H., Todaka, E., Mori, C., 2005. Necessity to measure PCBs and organochlorine pesticide concentrations in human umbilical cords for fetal exposure assessment. Environmental Health Perspectives 113, 297-303.

Glynn, A., Aune, M., Darnerud, P., Cnattingius, S., Bjerselius, R., Becker, W., Lignell, S., 2007. Determinants of serum concentrations of organochlorine compounds in Swedish pregnant women: a cross-sectional study. Environmental Health 6, 2.

Glynn, A.W., Granath, F., Aune, M., Atuma, S., Darnerud, P.O., Bjerselius, R., Vainio, H., Weiderpass, E., 2003. Organochlorines in Swedish women: Determinants of serum concentrations. Environmental Health Perspectives 111, 349-355.

Goni, F., Lopez, R., Etxeandia, A., Millan, E., Amiano, P., 2007. High throughput method for the determination of organochlorine pesticides and polychlorinated biphenyls in human serum. Journal of Chromatography B: Analytical Technologies in the Biomedical and Life Sciences 852, 15-21.

Hagmar, L., Bjork, J., Sjodin, A., Bergman, A., Erfurth, E.M., 2001. Plasma levels of persistent organohalogens and hormone levels in adult male humans. Archives of environmental health 56, 138-143.

Hovander, L., Athanasiadou, M., Asplund, L., Jensen, S., Wehler, E.K., 2000. Extraction and cleanup methods for analysis of phenolic and neutral organohalogens in plasma. Journal of Analytical Toxicology 24, 696-703.

Itoh, H., Iwasaki, M., Hanaoka, T., Kasuga, Y., Yokoyama, S., Onuma, H., Nishimura, H., Kusama, R., Tsugane, S., 2009. Serum organochlorines and breast cancer risk in Japanese women: A case-control study. Cancer Causes and Control 20, 567-580.

Jakszyn, P., Go, F., Etxeandia, A., Vives, A., Mill, E., Lez, R., Amiano, P., Ardanaz, E., Barricarte, A., Chirlaque, M.D., Dorronsoro, M., Larraga, N., Martez, C., Navarro, C., Rodruez, L., Schez, M.J., Tormo, M.J., Gonzez, C.A., Agudo, A., 2009. Serum levels of organochlorine pesticides in healthy adults from five regions of Spain. Chemosphere 76, 1518-1524.

James, R.A., Hertz-Picciotto, I., Willman, E., Keller, J.A., Judith Charles, M., 2002. Determinants of serum polychlorinated biphenyls and organochlorine pesticides 
measured in women from the Child Health and Development Study cohort, 19631967. Environmental Health Perspectives 110, 617-624.

Jimenez Torres, M., Campoy Folgoso, C., Canabate Reche, F., Rivas Velasco, A., Cerrillo Garcia, I., Mariscal Arcas, M., Olea-Serrano, F., 2006. Organochlorine pesticides in serum and adipose tissue of pregnant women in Southern Spain giving birth by cesarean section. Science of The Total Environment 372, 32-38.

Kaiser, J., 2000. Endocrine disrupters: Panel cautiously confirms low-dose effects. Science 290, 695-697.

Kang, J.H., Park, H., Chang, Y.S., Choi, J.W., 2008. Distribution of organochlorine pesticides (OCPs) and polychlorinated biphenyls (PCBs) in human serum from urban areas in Korea. Chemosphere 73, 1625-1631.

King, H., Aubert, R.E., Herman, W.H., 1998. Global burden of diabetes, 1995-2025: prevalence, numerical estimates, and projections. Diabetes Care 21, 1414-1431.

Koppen, G., Covaci, A., Van Cleuvenbergen, R., Schepens, P., Winneke, G., Nelen, V., van Larebeke, N., Vlietinck, R., Schoeters, G., 2002. Persistent organochlorine pollutants in human serum of 50-65 years old women in the Flanders Environmental and Health Study (FLEHS). Part 1: concentrations and regional differences. Chemosphere 48, 811-825.

Kumar, K.S., Watanabe, K., Takemori, H., Iseki, N., Masunaga, S., Takasuga, T., 2005. Analysis of UNEP priority POPs using HRGC-HRMS and their contamination profiles in livers and eggs of great cormorants (Phalacrocorax carbo) from Japan. Archives of Environmental Contamination and Toxicology 48, 538-551.

Lee, D.-H., Jacobs, D.R., Porta, M., 2007a. Association of serum concentrations of persistent organic pollutants with the prevalence of learning disability and attention deficit disorder. Journal of Epidemiology and Community Health 61, 591-596.

Lee, D.-H., Steffes, M.W., Sjödin, A., Jones, R.S., Needham, L.L., Jacobs, D.R., Jr., 2010. Low Dose of Some Persistent Organic Pollutants Predicts Type 2 Diabetes: A Nested Case-Control Study. Environ Health Perspect 118.

Lee, D.H., Lee, I.K., Song, K., Steffes, M., Toscano, W., Baker, B.A., Jacobs Jr, D.R., 2006. A strong dose-response relation between serum concentrations of persistent organic pollutants and diabetes: Results from the National Health and Examination Survey 1999-2002. Diabetes Care 29, 1638-1644.

Lee, S.A., Dai, Q., Zheng, W., Gao, Y.T., Blair, A., Tessari, J.D., Tian Ji, B., Shu, X.O., 2007b. Association of serum concentration of organochlorine pesticides with dietary intake and other lifestyle factors among urban Chinese women. Environment International 33, 157-163.

Luzardo, O.P., Goethals, M., Zumbado, M., Álvarez-Leon, E.E., Cabrera, F., Serra-Majem, L., Boada, L.D., 2006. Increasing serum levels of non-DDT-derivative organochlorine pesticides in the younger population of the Canary Islands (Spain). Science of The Total Environment 367, 129-138.

Masuda, Y., Haraguchi, K., Kono, S., Tsuji, H., Päpke, O., 2005. Concentrations of dioxins and related compounds in the blood of Fukuoka residents. Chemosphere 58, 329344. 
Meeker, J.D., Altshul, L., Hauser, R., 2007. Serum PCBs, p,p'-DDE and HCB predict thyroid hormone levels in men. Environmental Research 104, 296-304.

Minh, T.B., Watanabe, M., Kajiwara, N., Iwata, H., Takahashi, S., Subramanian, A., Tanabe, S., Watanabe, S., Yamada, T., Hata, J., 2006. Human Blood Monitoring Program in Japan: Contamination and Bioaccumulation of Persistent Organochlorines in Japanese Residents. Arch Environ Contam Toxicol.

Muir, D.C.G., Howard, P.H., 2006. Are there other persistent organic pollutants? A challenge for environmental chemists. Environmental Science and Technology 40, 7157-7166.

Patterson, J.D.G., Wong, L.-Y., Turner, W.E., Caudill, S.P., DiPietro, E.S., McClure, P.C., Cash, T.P., Osterloh, J.D., Pirkle, J.L., Sampson, E.J., Needham, L.L., 2009. Levels in the U.S. Population of those Persistent Organic Pollutants (2003-2004) Included in the Stockholm Convention or in other Long-Range Transboundary Air Pollution Agreements. Environmental Science \& Technology 43, 1211-1218.

Petrik, J., Drobna, B., Pavuk, M., Jursa, S., Wimmerova, S., Chovancova, J., 2006. Serum PCBs and organochlorine pesticides in Slovakia: Age, gender, and residence as determinants of organochlorine concentrations. Chemosphere 65, 410-418.

Ramos, J.J., Gomara, B., Fernandez, M.A., Gonzalez, M.J., 2007. A simple and fast method for the simultaneous determination of polychlorinated biphenyls and polybrominated diphenyl ethers in small volumes of human serum. Journal of Chromatography A 1152, 124-129.

Rusiecki, J.A., Baccarelli, A., Bollati, V., Tarantini, L., Moore, L.E., Bonefeld-Jorgensen, E.C., 2008. Global DNA hypomethylation is associated with high serum-persistent organic pollutants in Greenlandic inuit. Environmental Health Perspectives 116, 1547-1552.

Sagiv, S.K., Thurston, S.W., Bellinger, D.C., Tolbert, P.E., Altshul, L.M., Korrick, S.A., 2010. Prenatal Organochlorine Exposure and Behaviors Associated With Attention Deficit Hyperactivity Disorder in School-Aged Children. Am. J. Epidemiol. 171, 593-601.

Sandau, C.D., Sjödin, A., Davis, M.D., Barr, J.R., Maggio, V.L., Waterman, A.L., Preston, K.E., Preau Jr, J.L., Barr, D.B., Needham, L.L., Patterson Jr, D.G., 2003. Comprehensive solid-phase extraction method for persistent organic pollutants. Validation and application to the analysis of persistent chlorinated pesticides. Analytical Chemistry 75, 71-77.

Sawada, N., Iwasaki, M., Inoue, M., Itoh, H., Sasazuki, S., Yamaji, T., Shimazu, T., Tsugane, S., 2010. Plasma organochlorines and subsequent risk of prostate cancer in Japanese men: A nested case-control study. Environmental Health Perspectives 118, 659-665.

Shen, L., Wania, F., 2005. Compilation, Evaluation, and Selection of Physical-Chemical Property Data for Organochlorine Pesticides. pp. 742-768.

Snedeker, S.M., 2001. Pesticides and breast cancer risk: A review of DDT, DDE and dieldrin. Environmental Health Perspectives 109, 35-47.

Son, H.K., Kim, S.A., Kang, J.H., Chang, Y.S., Park, S.K., Lee, S.K., Jacobs, D.R., Lee, D.H., 2010. Strong associations between low-dose organochlorine pesticides and type 2 diabetes in Korea. Environment International 36, 410-414. 
Sundberg, S.E., Ellington, J.J., Evans, J.J., 2006. A simple and fast extraction method for organochlorine pesticides and polychlorinated biphenyls in small volumes of avian serum. Journal of Chromatography B 831, 99-104.

Takasuga, T., Senthilkumar, K., Takemori, H., Ohi, E., Tsuji, H., Nagayama, J., 2004a. Impact of FEBRA (fermented brown rice with Aspergillus oryzae) intake and concentrations of PCDDs, PCDFs and PCBs in blood of humans from Japan. Chemosphere 57, 1409-1426.

Takasuga, T., Senthilkumar, K., Takemori, H., Ohi, E., Tsuji, H., Nagayama, J., 2004b. Impact of fermented brown rice with Aspergillus oryzae (FEBRA) intake and concentrations of polybrominated diphenylethers (PBDEs) in blood of humans from Japan. Chemosphere 57, 795-811.

Takasuga, T., Senthilkumar, K., Tsuji, H., Nagayama, J., 2006. Impact of fermented brown rice with Aspergillus oryzae intake and concentrations of organochlorine pesticides in blood of humans from Japan. Bulletin of Environmental Contamination and Toxicology 76, 752-759.

Thomas, G.O., Wilkinson, M., Hodson, S., Jones, K.C., 2006. Organohalogen chemicals in human blood from the United Kingdom. Environmental Pollution 141, 30-41.

Torres-Sánchez, L., Rothenberg, S.J., Schnaas, L., Cebrián, M.E., Osorio, E., Hernández, M.d.C., García-Hernández, R.M., Rio-Garcia, C.d., Wolff, M.S., López-Carrillo, L., 2007. In Utero p,p'-DDE Exposure and Infant Neurodevelopment: A Perinatal Cohort in Mexico. Environ Health Perspect 115.

Torres-Sánchez, L., Schnaasb, L., Cebriánc, M.E., Hernándezb, M.d.C., Valenciab, E.O., Hernándezc, R.M.G., López-Carrilloa, L., 2009. Prenatal dichlorodiphenyldichloroethylene (DDE) exposure and neurodevelopment: A follow-up from 12 to 30 months of age. NeuroToxicology 30, 1162-1165.

Tsukino, H., Hanaoka, T., Sasaki, H., Motoyama, H., Hiroshima, M., Tanaka, T., Kabuto, M., Turner, W., Patterson Jr, D.G., Needham, L., Tsugane, S., 2006. Fish intake and serum levels of organochlorines among Japanese women. Science of the Total Environment 359, 90-100.

Turyk, M., Anderson, H., Knobeloch, L., Imm, P., Persky, V., 2009. Organochlorine exposure and incidence of diabetes in a cohort of great lakes sport fish consumers. Environmental Health Perspectives 117, 1076-1082.

Turyk, M.E., Anderson, H.A., Freels, S., Chatterton Jr, R., Needham, L.L., Patterson Jr, D.G., Steenport, D.N., Knobeloch, L., Imm, P., Persky, V.W., 2006. Associations of organochlorines with endogenous hormones in male Great Lakes fish consumers and nonconsumers. Environmental Research 102, 299-307.

Turyk, M.E., Anderson, H.A., Persky, V.W., 2007. Relationships of thyroid hormones with polychlorinated biphenyls, dioxins, furans, and DDE in adults. Environmental Health Perspectives 115, 1197-1203.

Wania, F., Mackay, D., 1995. A global distribution model for persistent organic chemicals. Science of the Total Environment 160-161, 211-232.

Wolff, M.S., Berkowitz, G.S., Brower, S., Senie, R., Bleiweiss, I.J., Tartter, P., Pace, B., Roy, N., Wallenstein, S., Weston, A., 2000. Organochlorine exposures and breast cancer risk in New York City women. Environmental Research 84, 151-161. 
Wolff, M.S., Toniolo, P.G., Lee, E.W., Rivera, M., Dubin, N., 1993. Blood levels of organochlorine residues and risk of breast cancer. Journal of the National Cancer Institute 85, 648-652.

Xu, X., Dailey, A.B., Talbott, E.O., Ilacqua, V.A., Kearney, G., Asal, N.R., 2010. Associations of serum concentrations of organochlorine pesticides with breast cancer and prostate cancer in U.S. adults. Environmental Health Perspectives 118, 60-66.

Zumbado, M., Goethals, M., Alvarez-Leon, E.E., Luzardo, O.P., Cabrera, F., Serra-Majem, L., Dominguez-Boada, L., 2005. Inadvertent exposure to organochlorine pesticides DDT and derivatives in people from the Canary Islands (Spain). Science of The Total Environment 339, 49-62. 


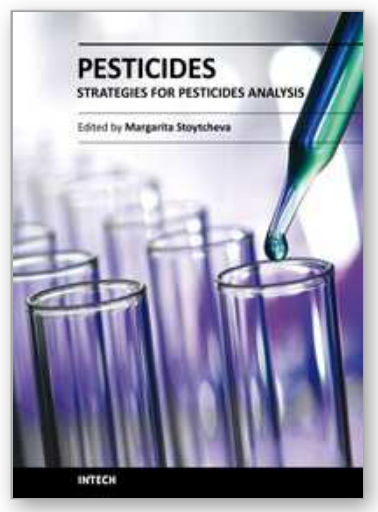

\author{
Pesticides - Strategies for Pesticides Analysis \\ Edited by Prof. Margarita Stoytcheva
}

ISBN 978-953-307-460-3

Hard cover, 404 pages

Publisher InTech

Published online 21, January, 2011

Published in print edition January, 2011

This book provides recent information on various analytical procedures and techniques, representing strategies for reliability, specificity, selectivity and sensitivity improvements in pesticides analysis. The volume covers three main topics: current trends in sample preparation, selective and sensitive chromatographic detection and determination of pesticide residues in food and environmental samples, and the application of biological (immunoassays-and biosensors-based) methods in pesticides analysis as an alternative to the chromatographic methods for "in situ" and "on line" pesticides quantification. Intended as electronic edition, providing immediate "open access" to its content, the book is easy to follow and will be of interest to professionals involved in pesticides analysis.

\title{
How to reference
}

In order to correctly reference this scholarly work, feel free to copy and paste the following:

Jung-Ho Kang and Yoon-Seok Chang (2011). Organochlorine Pesticides in Human Serum, Pesticides Strategies for Pesticides Analysis, Prof. Margarita Stoytcheva (Ed.), ISBN: 978-953-307-460-3, InTech, Available from: http://www.intechopen.com/books/pesticides-strategies-for-pesticides-analysis/organochlorinepesticides-in-human-serum

\section{INTECH}

open science | open minds

\section{InTech Europe}

University Campus STeP Ri Slavka Krautzeka 83/A 51000 Rijeka, Croatia Phone: +385 (51) 770447 Fax: +385 (51) 686166 www.intechopen.com

\section{InTech China}

Unit 405, Office Block, Hotel Equatorial Shanghai No.65, Yan An Road (West), Shanghai, 200040, China 中国上海市延安西路65号上海国际贵都大饭店办公楼 405 单元 Phone: +86-21-62489820

Fax: $+86-21-62489821$ 
(C) 2011 The Author(s). Licensee IntechOpen. This chapter is distributed under the terms of the Creative Commons Attribution-NonCommercialShareAlike-3.0 License, which permits use, distribution and reproduction for non-commercial purposes, provided the original is properly cited and derivative works building on this content are distributed under the same license. 